\title{
THE IMPACT OF SUBSIDY POLICY ON BIOGAS PLANTS IN SLOVAKIA
}

\section{Ján Lajda * Zuzana Lajdová, Peter Bielik}

Slovak University of Agriculture in Nitra, Slovakia

Recently, renewable energy sources (RES) have become very popular all over the EU. Subsidy policies have provided huge amount of money flowing into the sector which were necessary for its development. In Slovakia, favourable legislation was one of triggers for building biogas plants using anaerobic fermentation for biogas and further electric energy production. This paper examines how subsidy policy has stimulated biogas sector over the years and the consequences arising from the legislation.

Keywords: Biogas, anaerobic fermentation, biogas plants, subsidies

\section{Introduction}

European Biomass Association (2013) states in its document that the usage of biomass as a bioenergy source will play vital part in achieving the ambitious goal leading to $20 \%$ of the final energy consumption to be produced by renewable sources by 2020, which is approved by the Renewable Energy Directive.

Zacharda (2012) considers using biomass for anaerobic fermentation in biogas stations as one of the most advanced technologies as a source of renewable energy. Realization of projects for building Biogas stations (BGP) in Slovakia had to wait for an adoption of legislative guarantees, so that electric energy and heat produced from biogas would have long-term consumption ensured for guaranteed prices. On the other hand, Energia Press s. r. o. (2014) points out that it has been several years now that consumers pay surcharge added to the price of electricity for renewable energy sources. In 2013, it reached 343 million EUR. Among the largest beneficiaries of the surcharge there are also some producers of electricity from biomass. URSO estimates that the amount of the surcharge should exceed 405 million EUR in 2014. Zacharda (2012) further explains that these conditions were necessary due to high capital needs to build a BGP. The total price for a BGP with the most commonly installed capacity in Slovakia at the level of $1 \mathrm{MW}$ of electricity is over 3 million EUR. There is 3-3.5 thousand EUR for each $1 \mathrm{kWh}$ of installed capacity. The Act. no 309/2009 Coll. about promotion of renewable energy guarantees price of electric energy produced in BGPs for duration of 15 years. This removed uncertainty and risk for investors in terms of return on investments.

Figure 1 records the purchase price of electricity from biogas in half-year intervals since
2010. Purchase prices tend to fall. Trend is partly justified, as with passing time it is expected that new technologies for production of electricity from renewable energy sources will be more efficient, and thus, will generate more energy. The regulation of URSO in 2012 says that the purchase price for BGPs with capacity up to $1 \mathrm{MW}$ of electricity falls again in 2013. Those investors who managed to operate BGPs with capacity of $1 \mathrm{MW}$ until 31. 12. 2012 are eligible for the purchase price of electricity at the level of 136.33 EUR. Those BGPs that became operational after 1. 1. 2013 pay 134.08 EUR/MW. A BGP put into operation on 30.6 .2011 , now gains guaranteed price for 15 years at the level of 148.72 EUR / MW. The decline in prices is notable and there were indications for their further reduction in summer 2013 (Brestensky, 2012).

Since 2014, the Regulatory Office for Network Industries (URSO) launches a new pricing methodology for purchasing prices of electricity produced through anaerobic fermentation in BGPs. Since 2014, there have been four price levels instead of two as follows: up to $250 \mathrm{~kW}$, from $250 \mathrm{~kW}$ up to $500 \mathrm{~kW}$, from $500 \mathrm{~kW}$ up to 750 kW and above $750 \mathrm{~kW}$ (see Table 1). On average, $20 \%$ drop in the guaranteed price of electricity changes profitability of BGPs.

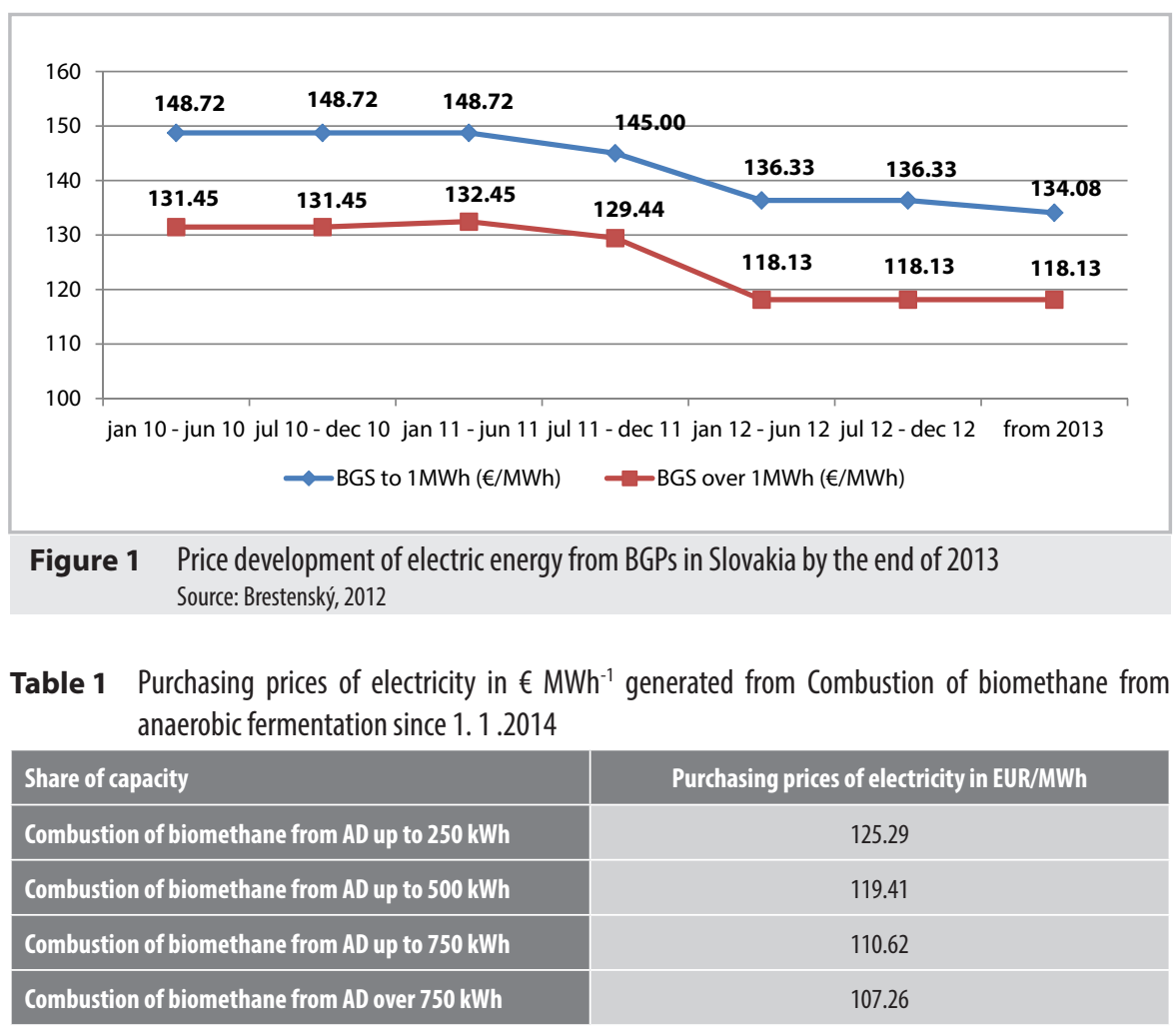

Source: Act URSO 221/2013 
The new concept of guaranteed purchasing prices for electricity generation from biogas could generate greater concentration of farms in construction of smaller BGPs. The guaranteed price for BGP with power up to $250 \mathrm{~kW}$ will be 125.29 EUR per MWh, which is still less than the guaranteed price for BGP with power up to $1 \mathrm{MW}$ for the year 2013 at the level 134.08 EUR per MWh. Finally, it may happen that the total construction of BGPs will drop down, since smaller BGPs have longer payback periods even if an increase in prices of corn silage is not as harmful as in case of bigger BGPs. In times of climbing agricultural commodities prices, BGPs show weak economic performance and the world prices of agricultural commodities recorded levels above their average in 5 years over the past 7 years. A support for BGPs with lower performance could thus motivate the use of animal products as a source of electricity and heat. Changes in purchasing prices may also lead to changes in BGPs conceptions, so there will be a greater emphasis on heat utilization. The heat not consumed in fermentation process is produced in amounts comparable to amount of electricity produced (Karkulin, 2012).

The aim of the paper is to examine how subsidy policy has stimulated biogas sector over the years and the consequences arising from the legislation.

\section{Materials and methods}

Our research was based on processing of the secondary data. The paper has an explorative character, thus the main aim was to find out how changes in legislative environment have had impacts on the biogas industry.

The data were used from the following sources:

$\square$ Agromagazin, year 14, no. 12/2012.

$\square$ Regulatory Office for Network Industries (URSO) Act 221/2013.

Our research was carried out via the following steps:

$\square$ We compared available literature resources dealing with our research issue.

$\square$ Secondly, data were examined separately for each year for the period 2010-2014 in case of biogas industry and legislative support developments.

$\square$ Thirdly, the results from both groups development of the sector and development of the legislation for individual years were matched.

$\square$ Then, the matched data were compared with each other.

$\square$ Finally, the comparisons were analyzed and discussed.

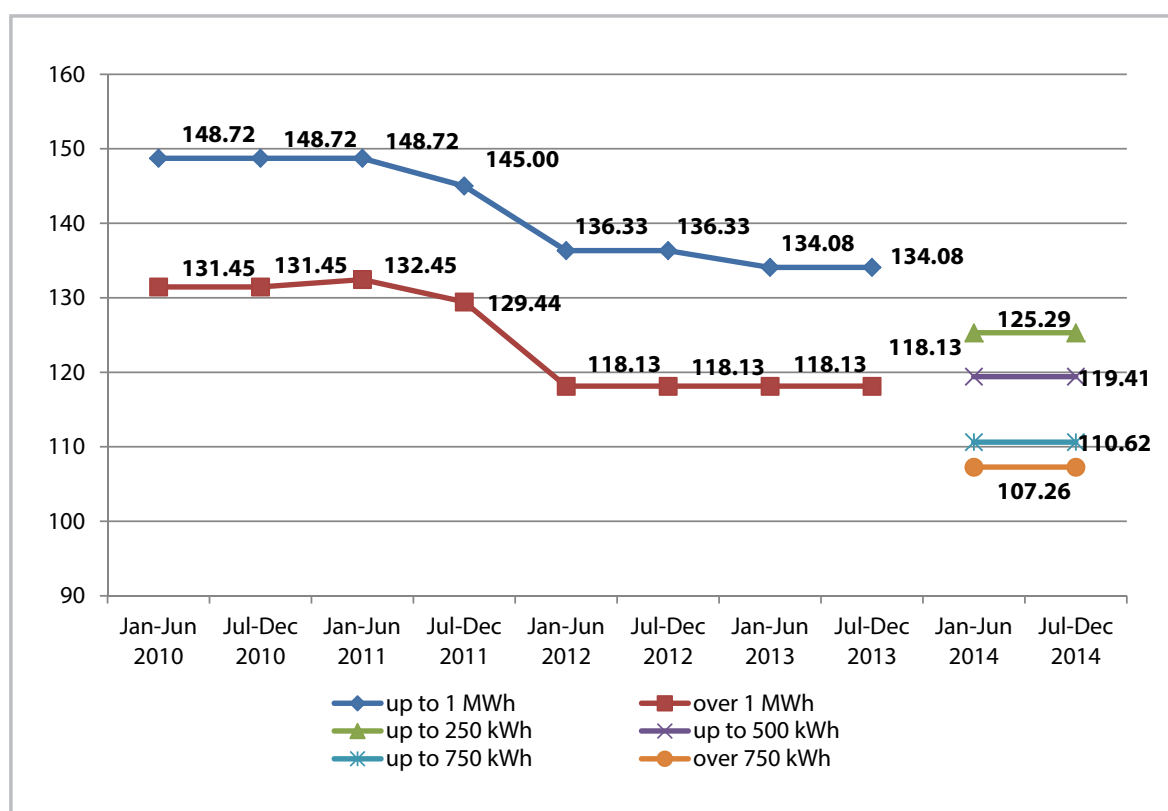

Figure 2 Development of purchasing prices of electricity in EUR kWh-1 generated from Combustion of biomethane from anaerobic fermentation reflecting development of subsidies policy for years 2010-2014

Source: Brestenský, 2012; Act URSO 221/2013

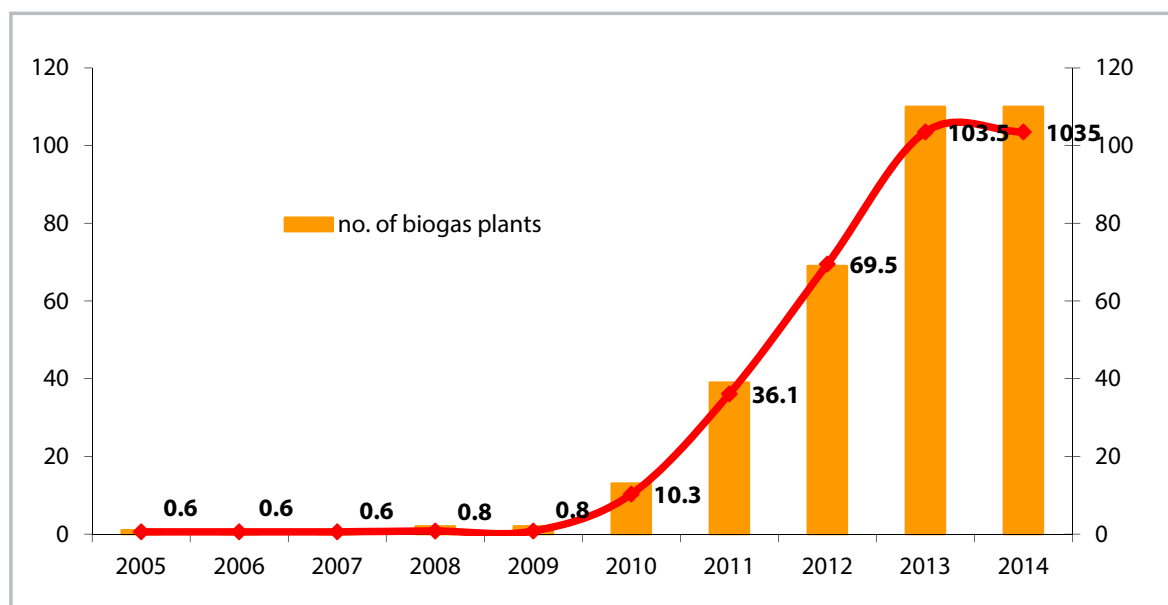

Figure 3 Development of biogas industry in Slovakia for years 2005-2014 Source: URSO

\section{Results and discussion}

Figure 2 shows development of legislation subsidizing biogas industry in Slovakia over the years. Since 2010, there were recognized two groups of BGPs, one was BGPs with size up to 1 MWh and the second was formed by BGPs over $1 \mathrm{MWh}$. The continual slightly decreasing trend was justified by technical development in the sector followed by decreasing costs of electricity production. However, since 2014 a new concept of subsidies has been launched with 4 different groups of BGPs depending on the sizes of the BGPs. The limit sizes are now $250 \mathrm{kWh}, 500 \mathrm{kWh}$ and $750 \mathrm{kWh}$. Moreover, there is a more important emphasis on heat utilization.
Figure 3 follows the biogas industry development in Slovakia. It is clear that the boom started in 2010 when 11 new BGPs were launched with the total electric capacity of $10.3 \mathrm{MWh}$. The trend was continually increasing until 2014 when the development suddenly stopped at total number of $110 \mathrm{BGPS}$ and $103.5 \mathrm{MWh}$ of total electric capacity.

Figure 4 indicates that the sharpest increase in number of BGPs was in 2013. Until 2014 , the increasing trend was experienced in the development of the biogas sector; however, there was not any new BGP registered in 2014 according to the official data by URSO. According to the Figure 2 it is clear that the introduction of the subsidies in 2010 for BGPs initiated usage of the 


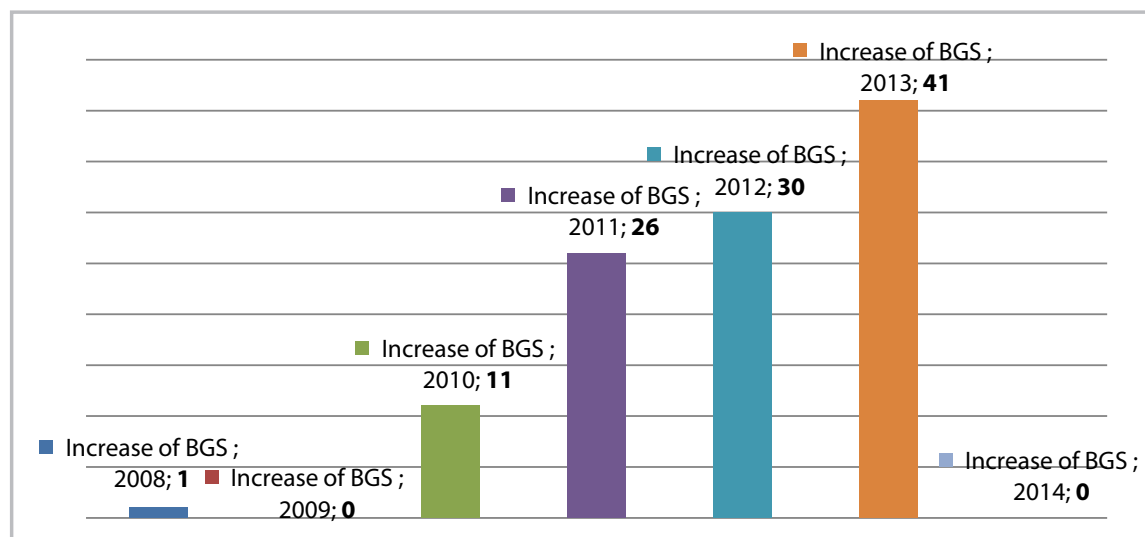

Figure 4 Annual changes in numbers of BGPs in Slovakia until 2014 Source: URSO

$A D$ technology for generating electric energy. The trend in subsidies was slightly decreasing with stable values since January 2012 until December 2013. During this period there was recorded the highest increase in launching new BGPs. In January 2014, there was introduced whole new subsidy policy that broke down biogas sector into 4 groups which left the most popular scale of BGP (1 MGW of capacity) launched in 2014 with lowest amount of purchasing price. The change in policy reflects to trends in other countries with more developed biogas industry and problems and negative externalities connected with BGPS of larger sizes. On the other hand, the change of subsidy policy for year 2014 highlights its volatility which means uncertainty in the sector which could be the main factor why there was no new BGP launched in 2014.

\section{Conclusion}

Producing electricity by burning biogas extracted from biomass via anaerobic digestion (AD) was originally designed as a waste treatment technology. However, the technology and further electricity production is unprofitable in current environment with market prices, so the subsidy policy was introduced in Slovakia to meet environmental targets set by the EU in 2010. It is clear that the legislation promoting anaerobic digestion (AD) is successful as it has enhanced building biogas plants with an increasing development. However, the character of the legislation had also drawbacks which caused further changes in subsidizing the biogas sector. Most significant change has been launched since 2014, and it might be the result of the fact that there is not any new biogas plant officially recorded by URSO in the very same year.

\section{Acknowledgements}

This work was co-funded by the European Community under the project no 26220220180: building Research center "AgroBiotech".

\section{References}

BRESTENSKÝ, V. 2012. Rozostavanú BPS sa oplatí dokončit' čo najskôr. In Agromagazín. 2012, č. 8, s. 32.

ENERGO PRESS S. R. 0. 2014. Na obnoviteliné zdroje priplácame už 343 miliónov eur. Poznáme TOP 10 "doplatkárov". 2014. [online]. [Accessed 2015-0104]. Available at : <http://www.energie-portal. sk/Dokument/na-obnovitelne-zdroje-priplacameuz-343-milionov-eur-pozname-top-10doplatkarov-102182.aspx>

EUROPEAN BIOMASS ASSOCIATION. 2013. A Biogas Road Map for Europe. [online]. 2013. [Accessed 2015-0108]. Available at: <http://www.aebiom.org/IMG/ pdf/Brochure_BiogasRoadmap_WEB.pdf> p. 4, 5, $12,17$.

KARKULIN, D. 2012. Agrotrade group, spol. s. r. o. ponúka komplexné riešenia pre bioplynové stanice. In Agromagazín, 2012, č. 8, s. 28-29.

KARKULIN, D. 2012. Bioplynové stanice znovu menej lukratívne, 0 slovo sa hlási suchá fermentácia. In Agromagazín, 2013, č. 10, s. 27, 29.

ZACHARDA, F. 2012. Ako d'alej v budovaní bioplynových zariadení. In Rolnícke noviny, 2012, č. 36, s. 21-22.

ZACHARDA, F. 2013. Budovat' BPS alebo nie? In Rolnícke noviny, 2013, č. 41, s. 11, 16.

\section{Contact address} much uncertainty and speculations.

So called G-component was also imposed on RES producers since 1. 1. 2014, a character of which is the same as a tax levied on electricity production from RES. This component decreases revenues which were supposed to be guaranteed at certain levels for 15 years for each BGP. This is yet another change in legislation making the biogas sector less profitable and creating doubts about future legislative environment.

Today, biogas sector is dependent on favourable and supporting legislative condition as the technology used in the BGPs is too expensive to be competitive with fossil energy sources. On one hand, correctly adjusted legislation is inevitable for the development of this sector, but on the other hand, there have always been political risks involved, more than in any other industry. Such a fast changing legislation may indicate that the government was not sure what they were doing in the first place and hopefully, future adjustments will be made more carefully just as well as goals will be set.
*Ing. Ján Lajda, Slovak University of Agriculture, Faculty of Economics and Management, Department of Economics, Tr. Andreja Hlinku 2, 94976 Nitra, Slovak Republic e-mail: lajda.j@gmail.com 